\title{
Stepping through the looking glass: A new relationship between professional foresters and forest technologists
}

\author{
by E.V. (Van) Scoffield ${ }^{1}$
}

\begin{abstract}
The regulation of forest professionals in British Columbia is undergoing dramatic change. The long-standing close working relationship between professional foresters and forest technologists is now entrenched in legislation. A new Foresters Act came into law on June 20, 2003. It authorizes the Association of British Columbia Professional Foresters to regulate forest technologists as well as professional foresters. This new approach to the regulation of the two groups will build upon their healthy relationship and strengthen the forestry team as it grapples with the challenges ahead.
\end{abstract}

Key words: forest professionals, professional forester, forest technologist, British Columbia, Foresters Act, regulation

La législation encadrant les professionnels de la foresterie en Colombie-Britannique connait un changement drastique. L'étroite relation de travail existante entre les forestiers professionnels et les technologistes forestiers est désormais incluse dans la législation. Une nouvelle Loi des Forestiers a pris effet le 20 juin 2003. Elle permet à l'Association of British Columbia Professional Foresters de régir les technologistes forestiers ainsi que les forestiers professionnels. Cette nouvelle approche en matière de législation des deux groupes s'établira sur une saine relation entre les parties et renforcera l'équipe forestière alors qu'elle fait face à de nouveaux défis.

Mots-clés: professionnels de la forêt, forestier professionnel, technologiste forestier, Colombie-Britannique, Loi des Forestiers, législation

\section{Introduction}

Unrelenting change and uncertainty remain the order of the day in British Columbia forestry circles as the sector tries to cope with severe economic stains, ongoing trade battles, government down-sizing, First Nations issues and unprecedented forest policy change. Not surprisingly, the regulation of forest professionals in B.C. is also undergoing dramatic change. A new Foresters Act-considerably clarifying and strengthening the mandate and powers of the Association of British Columbia Professional Foresters (ABCPF) and authorizing a broadening of its membership to include forest technologists-came into law on June 20, 2003. The latter aspect has been the subject of much curiosity among professional foresters and forest technologists across Canada.

In November 2001, the councils of the Applied Science Technologists and Technicians of B.C. (ASTTBC) and the ABCPF agreed to consider a new approach to the regulation of professional foresters and forest technologists. In January 2002, a joint ABCPF/ASTTBC task force was charged with the task of bringing recommendations to the two councils by the end of April.

On May 1, 2002, following four months of intense effort, the task force tabled its report. The central recommendations were that forest technologists should be regulated under the Foresters Act as members of the ABCPF and that they should enjoy the right to independently practice aspects of professional forestry. The report also recommended that forest technologists within the ABCPF should use the title Registered Forest Technologist (RFT) and enjoy full and equal membership rights, including the right to be elected to the association's council. Finally, the report recommended that the name of the association should change slightly to the Association of British Columbia Forest Professionals to better reflect the broadened membership. (The sections of the new Foresters Act autho-

${ }^{1}$ Executive Director, Association of British Columbia Professional Foresters, 1030 - 1188 West Georgia Street, Vancouver, BC V6E 4A2. E-mail: vscoffield@rpf-bc.org rizing the new name have not yet been brought in to force, but are expected to be in force before the start of the association's next fiscal year on December 1, 2003. To avoid confusion, this article uses the association's current name and the ABCPF acronym.) The report did not deal with the proposed right of RFTs to practice independently, suggesting instead that further work was required in this area.

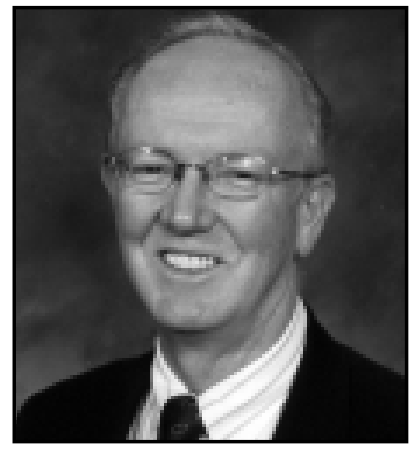

E.V. (Van) Scoffield
The report was endorsed by both councils before the end of May 2002. A copy of the full report can be found on the ABCPF Web site (www.rpf-bc.org/download/newrelationship.pdf).

\section{The Context}

To understand why it made sense for the ABCPF to embrace this new relationship, it helps to understand some of the context surrounding the decision. Forest policy change was a key component of the B.C. Liberal Party's election platform and they proceeded to make extensive forest policy changes shortly after they were elected in May 2001. Central to their changes was a decision to abandon the Forest Practices Code of B.C. Act, which regulated forest practices in considerable detail, in favour of a results-based approach. The rationale was that, while the code did in fact bring about an improvement in forest practices, its prescriptive, processdriven approach imposed an unnecessary regulatory burden on both industry and government. Results-based approaches, they argued, can achieve the same or better results at much less cost while allowing more site-specific and innovative solutions to be applied. In November 2002, the new Forest and Range Practices Act (FRPA) implementing this policy shift was passed by the B.C. Legislature. 
In discussions with government in mid-2001, the ABCPF supported the results-based approach provided it was accompanied by increased professional reliance, among other things. In other words, a key to the new regime should be its reliance on the ability of professionals in the field to achieve the government-stipulated results by using their judgement to make site-specific decisions together with the fact they can be held professionally accountable for those decisions. The ABCPF's concern was that under the code, forest practice decisions had been heavily circumscribed by regulation leaving little scope for professional judgement.

From government's perspective, increased professional reliance promised to enhance the effectiveness of the new regime and to allay public fears that industry was being given too much freedom. From the ABCPF's perspective, the appeal was that such an approach would allow professional foresters to better fulfil their potential. However, the ABCPF also argued that, for increased professional reliance to be successful, the Foresters $A c t^{2}$ would have to be strengthened. Government accepted the argument. Just over a year later, a substantially re-written Foresters Act was tabled in the B.C. Legislature.

\section{Benefits of Bringing Professional Foresters and Forest Technologists Together}

It soon became apparent to the $\mathrm{ABCPF}$ and $\mathrm{ASTTBC}$ that there would be many benefits to strengthening the relationship between the two groups and bringing both groups under one regulatory umbrella. Among the benefits identified were the following:

- Forest technologists would gain rights to practice aspects of professional forestry - something that for many years had been denied them under the Applied Science Technologists and Technicians Act.

- Forest technologists would be brought to the same level of regulation as professional foresters, and would be subject to the same code of ethics, practice standards and accountability measures.

- There would be better protection of the public interest.

- Forest technologists would bear a more appropriate share of the increased responsibilities and liabilities arising under a results-based approach to forest management.

- The voice of forestry practitioners would be stronger and more unified.

- There would be greater clarity of roles and responsibilities.

- There would be improved career path potential for forest technologists.

In addition, from an $\mathrm{ABCPF}$ perspective, there was the potential, over time, of an expanded membership and increased financial resources. While the ASTTBC membership includes only a few hundred forest technologists, it is estimated that there are, in fact, several thousand of them working in B.C., although some may not be practising professional forestry as defined in the new Foresters Act.

Following endorsement of the report by both councils in May 2002, efforts shifted to ensuring that the new relationship was

\footnotetext{
${ }^{2}$ The ABCPF also advocated that other relevant professional legislation also be strengthened. In particular, the absence of self-regulatory legislation for biologists operating in the resource management field was a concern. Subsequently, the B.C. Legislature passed the College of Applied Biology Act in November 2002 and, in April 2003, passed an upgraded version of the Agrologists Act. An improved Engineers and Geoscientists Act is likely to proceed during 2004.
}

\section{Questions and Answers}

Q: Why did the ASTTBC propose that a new relationship be considered?

A: In early 2000, the ASTTBC began discussions with the Association of Engineers and Geoscientists of B.C. (APEGBC) regarding new approaches to the regulation of engineers and geoscientists on the one hand and engineering technologists on the other. By mid 2001, those talks were progressing well and clearly pointed to the possible merger of the two organizations. Because some 90 per cent of ASTTBC's 8,000 members are involved in engineering technologies of one variety or another, the question arose as to what would happen to the remaining ten per cent of ASTTBC's membership, roughly half of whom were forest technologists. Thus, instigation of the talks with the $\mathrm{ABCPF}$ was primarily driven by the need to answer that question. Of note, in June 2003 the APEGBC and ASTTBC councils formally authorized a merger of the two organizations. Amendment of the Engineers and Geoscientists Act to authorize the merger is expected to occur in 2004.

Q: Why was the joint task force given so little time? A: When the talks with ASTTBC began in January 2002, development of revisions to the Foresters Act was already well advanced. Indeed, in anticipation of the planned tabling of the amendments in the fall 2002 sitting of the B.C. Legislature, two drafts of the legislative proposals had been circulated to ABCPF members for review and comment in October and December of 2001 and it was known that by mid 2002 the legislative drafting process within government would begin in earnest behind closed doors. The timing of the legislative drafting process obliged the $\mathrm{ABCPF}$ to clarify what it wanted in the new Foresters Act by mid-2002.

Q: Where do forest technicians fit into this scheme? A: In British Columbia, it is generally understood that "technologists" hold two-year technology diplomas whereas "technicians" hold one-year diplomas or, in some cases, even less formal post-secondary education. The ABCPF has decided admission as an RFT will require at least a two-year forest technology diploma from an accredited program or equivalent, plus post-enrolment work experience under supervision and successful completion of a registration examination appropriate for the forest technology discipline. Hence the title, Registered Forest Technologist. Those with lesser education, such as forest technicians, will be required to upgrade their academic record.

legislatively authorized and enabled. Section 20(2) of the new Foresters Act achieved that end. It reads as follows:

"A registered forest technologist may engage in aspects of the practice of professional forestry to the extent consistent with their education, training and experience

\footnotetext{
${ }^{3}$ To take effect, the Foresters Act requires that bylaws must be ratified by at least two-thirds of the voting members who vote in a ballot. At the time of writing, the outcome of the current bylaw ballot is not known.

${ }^{4}$ Not yet approved by the ABCPF council at the time of writing.
} 
(a) independently, when carrying out functions described in the bylaws for this purpose,

(b) while executing, supervising the execution of, or inspecting work designed by a professional forester admitted under Section 14 or special permit holder acting within the scope of their permit, or

(c) under the supervision of a professional forester admitted under Section 14 or a special permit holder acting within the scope of their permit."

A decision was made not to describe the rights conveyed in clause (a) in detail in the legislation, relying instead on the association's bylaws and council guidelines for that purpose. This approach was taken because guidelines can be more readily adjusted to keep pace with the evolving nature of forestry practice and the relationship between professional foresters and forest technologists, whereas legislation and even the association's bylaws cannot. With respect to clause (b), it should be noted that, under the former Foresters Act, these practice rights were available to anyone, but under the new Foresters Act, they are largely restricted to RFTs. With respect to clause (c), the former Foresters Act made these rights available to anyone and that remains the case in the new Foresters Act.

During the latter half of 2002 and the first half of 2003, the task force turned its mind to the wording of the bylaw to underpin Section 20(2) of the Foresters Act. This bylaw wording was included in a package of revisions to the entire set of existing bylaws made necessary by the changes to the Foresters Act. These new bylaws were adopted by council in July and put to the membership for ratification in August $^{3}$. The specific bylaw dealing with RFT practice rights repeats the language of Section 20(2) of the Foresters Act and adds that they may only practice independently in the following general practice areas: forest measurements, silviculture, forest operations, and forest protection. The bylaw also states that these rights of independent practice will be further described in council guidelines.

The task force also addressed the guidelines, a much more challenging task than the bylaw. The draft guidelines ${ }^{4}$ consist of a general characterization of the distinct roles of RFTs and RPFs, followed by a series of examples in each of the practice areas identified in the bylaw. The intent is that the association, its members and others will be able to extrapolate from the specific examples. The draft guidelines are available on the ABCPF Web site (www.rpf-bc.org/download/RFT-draftpracticeguidelines.pdf).

\section{Implementation to Proceed in Three Phases}

Assuming the new bylaws are ratified by the members and that the guidelines are endorsed by the ABCPF council, the integration of forest technologists into the ABCPF will occur in three phases. The fee structure and other requirements that forest technologist applicants will be subject to are structured to encourage as many as possible to join voluntarily prior to the commencement of the third phase.

The first phase will occur on December 1, 2003 with the transfer to the ABCPF of those ASTTBC forest technologist members (approximately 400 individuals) who authorize the transfer of their files. These transferees will be required to pay a transfer fee and, within three years, will have to pass a portion of the $\mathrm{ABCPF}$ registration exam. Barring basic deficiencies, they will not have to gain new work experience or be required to under- take additional coursework. To prepare for the initial influx of forest technologists and to deal with resultant workload, the ABCPF will increase its current staff complement of nine people to eleven in October 2003. The two new positions will be in the areas of admissions and communications.

The second phase comprises the two-year period between December 1, 2003 and November 30, 2005. During this period, applicants for RFT status will have to pay an application fee and pass a full registration exam within three years. Like the first phase transferees, in most cases they will not have to gain new work experience or undertake additional coursework.

The third phase starts on December 1, 2005 at which point the Foresters Act stipulates that RFT practice rights become legally enforceable. Forest technologist applicants after that date will have to meet the requirements of the second phase plus gain new work experience after they enrol. They may also have to complete additional coursework as determined on a case-bycase analysis of their application package and transcripts.

\section{Conclusion}

Not surprisingly, some professional foresters and forest technologists have found this initiative difficult to accept. On both sides, some fear a loss of identity. Some foresters fear the profession will be watered down. On the other hand, some technologists fear being second-class members within the new association.

Even within the ABCPF/ASTTBC joint task force, these fears and perceptions were very much in evidence during the early stages of its deliberations.

In the end, however, the members of the task force found inspiration in Lewis Carroll's book, Through the Looking Glass, in which Alice steps through a mirror and discovers that the world looks quite different on the other side. The task force found that unless it was prepared to step through the looking glass and let go of the current paradigm, the dynamic of "them" versus "us" was very hard to escape. However, when they did step through the looking glass and embrace the new paradigm of professional foresters and forest technologists as equal members of the forestry team, most of their fears dissipated and the challenges turned into opportunities.

Fortunately, feedback of various kinds indicates that most of the ABCPF and ASTTBC members have been able to step through the looking glass and embrace this initiative. This undoubtedly reflects the long-standing close working relationship between profession foresters and forest technologists in the field. While there will undoubtedly be some hurdles to overcome along the way, the ABCPF expects that this new approach to the regulation of the two groups will build upon that healthy past and strengthen the forestry team as it grapples with the dynamic challenges ahead.

\section{Acknowledgement}

The ABCPF would like to thank the members of the ABCPF/ASTTBC joint task force for their recommendations on the new approach to the regulation of professional foresters and forest technologists and their work on developing the draft practice guidelines for RFTs. The task force members are: Phil Blanchard, RPF; Steve Drosdovech; Al Gorley, RPF; John Gow, AScT; Mike Larock, RPF; John Leech, AScT; Peter Marshall, PhD, RPF; Ted Nodwell, CAE; Van Scoffield, RPF; Norm Shaw, AScT, ATE; and Geoff Tindale, AScT. 